\title{
血液透析患者におけるコレステロール結合能
}

$\begin{array}{lllllll}\text { 岡 } & \text { 徹 } & \text { 船江 } & \text { 仁美 } & \text { 平林 } & \text { 俊明 } & \text { 小林 } \\ \text { 中登 } \\ \text { 治 }\end{array}$

高砂市民病院 兵庫医科大学*

(昭和 57 年 11 月 17 日受付)

key words：コレステロール結合能 (serum cholesterol binding reserve), uremic toxin, uremic middle molecules

〈要旨〉

今回我々は血液透析患者の脂質代謝状態につき, コレステロールの turn over の面より検索を試み, コレステロー ル結合能（以下 SCBR と略す）を測定し，若干の知見を得たので報告する．腎機能別 SCBR 值は, 非糖尿病群では GFR $>50 \mathrm{ml} / \mathrm{min}$ のコントロール群 $(\mathrm{N}=12, \mathrm{SCBR}=37.5 \pm 13.8 \mathrm{mg} / \mathrm{d} l)$ に比し, GFR $<10 \mathrm{ml} / \mathrm{min}$ の腎不全群 $(\mathrm{N}=16, \mathrm{SCBR}=27.4 \pm 12.1 \mathrm{mg} / \mathrm{d} l)$ および血液透析群 $(\mathrm{N}=16, \mathrm{SCBR}=18.5 \pm 3.6 \mathrm{mg} / \mathrm{d} l)$ では $\mathrm{p}<0.1$ と有意の 低下を示した. また糖尿病群においても, コントロール群 $(\mathrm{N}=23, \mathrm{SCBR}=32.8 \pm 7.5 \mathrm{mg} / \mathrm{d} l)$ に比し, 腎不全群 $(\mathrm{N}=$ 7, $\mathrm{SCBR}=21.3 \pm 8.7 \mathrm{mg} / \mathrm{d} l)$ および血液透析群 $(\mathrm{N}=7, \mathrm{SCBR}=20.3 \pm 11.5 \mathrm{mg} / \mathrm{d} l)$ で $\mathrm{p}<0.1$ の有意な低下を 示し，腎機能低下とともに，SCBR の低下傾向がみられた。また長期透析例で, 糖尿病症例に異常低值を示す例が多 く認められた。

SCBR と血清コレステロール值, 中性脂肪, HDL-コレステロールとの間には有意の相関は見られなかった。 また SCBR と LCAT (Lecithin cholesterol acyltransferase) 活性の間に $\gamma=0.54$ と軽度の相関を認め, また SCBR と Apo $\mathrm{A}$ との間にも $\gamma=0.53$ と軽度の相関傾向を認めた。 1 回約 5 時間の血液透析の影響を 13 例につき検討したが, 全体に 透析後の SCBR の上昇傾向をみた。また in vivo にて uremic middle molecules を rat に静注後 SCBR を測定したが， 非投与群に比偟て有意の抑制が認められた。

以上の結果より, 腎不全状態ではSCBR の低下よりみてコレステロールの転送障害が存在し, 血管障害の進展に関 与するものと思われる. この SCBR の本体についてはなお不明瞭であり, 弚の低下機構には他の抑制因子の介在, ま た HDL の機能との関連が想定された。

\section{Serum cholesterol binding reserve in hemodialysis patients}

Tohru Oka, M. D., Hiromi Funae, Toshiaki Hirabayashi, M. D., Noboru Kobayashi, M. D., Takahiro Nakaji, M. D., Shozo Miki, M. D., Takeo Gotoh, M. D., Yoshikazu Fujita, M. D.*

Takasago City Hospital, and Hyogo College of Medicine*

Serum cholesterol binding reserve (SCBR) was measured in uremics from the viewpoint of complications and of hemodialysis treatment in comparison with control subjects (GFR of more than $50 \mathrm{ml} / \mathrm{min}$.). The correlation between SCBR and serum lipids was investigated in each group. Further more, the influence of uremic toxins (uremic small and middle molecules) on the SCBR value in vivo, was also studied in an animal experiment. SCBR was determined by a modification of Hsia's method. The subjects studied were 32 uremics (dialyzed, 16) 14 uremics with diabetes (dialyzed, 7) 35 subjects control (nondiabetic nephropathy, 12 ; diabetic nephropathy, 23). SCBR was significantly low in uremics with and without diabetes and not influenced by hemodialysis. Among the hemodialysis patients with a constantly low SCBR., the rate of uremics with diabetes predominated. A slightly positive correlation was observed between SCBR and LCAT and apoprotein A, but not between SCBR and TG, cholesterol and HDL-cholesterol. In the animal experiment using wistar albino rats, SCBR was slightly suppressed by the administration of uremic toxins in vivo, expecially $M$. M. obtained from uremics without diabetes.

These results suggest that SCBR as the function of cholesterol transport was partly influenced by uremic toxins, but further studies must be made in order to elucidate other related factors in uremia. These low SCBR levels may 
play a role in the acceleration of atherogenicity in uremics.

\section{緒言}

慢性腎不全患者では HDL コレステロール, LCAT 活 性の低下等, 脂質代謝に影響を及ほす諸現象が報告され ており,この脂質代謝異常の動脈硬化に及ぼす影響は興 味ある問題である。慢性血液透析患者では uremic substance の変動, ヘパリンの作用等さらに多くの要因を含 み, その脂質代謝の状態はより複雑な様相を呈し, 動脈 硬化に及ぼす影響はいまだ解明されていない。

今回，これらの点に注目し，コレステロールの turn overの面より検索を試み, コレステロール結合能 serum cholesterol binding reserve (以下 SCBR と略す) につ き慢性血液透析患者において, 動物実験を併用し検討し たので報告する。

\section{対象・方法}

対象は 98 例を,その基礎疾患に糖尿病の有無にしたが い, 糖尿病群 47 例と非糖尿病群 (慢性腎炎) 51 例に分類 し，それぞれを GFR $50 \mathrm{ml} / \mathrm{min}$ 以上群， $50 \sim 10 \mathrm{ml} / \mathrm{min}$ 群, $10 \mathrm{ml} / \mathrm{min}$ 以下であるが透析療法を受けていない腎 不全群，および血液透析群の 4 群ずつに分け，GFR 50 $\mathrm{m} l / \mathrm{min}$ 以上群をコントロールとした。血液透析群は糖 尿病性腎不全 7 例, 非糖尿病性 (慢性腎炎) 腎不全 16 例 の計 23 例で, 6 力月以上の安定した慢性血液透析療法を 受けており, 週 $2 \sim 3$ 回各々 $4 \sim 5$ 時間, 中空系型透析 器を用いて行っている. SCBR は Hsia らの方法にした がい' ${ }^{1)}, 12$ 時間以上絶食後, $0.5 \mathrm{~m} l$ の血清に超音波で破 砕したコレステロール結晶粉末 $10 \mathrm{mg}$ を添加, $37^{\circ} \mathrm{C} て ゙ 16$ 時間, 1 分間 40 回転で振盪混和, 室温にてワットマン No. 42 濾紙で未溶解コレステロール結晶を濾過, 酵素法 でコレステロール濃度を測定した，LCAT：長崎-赤沼 法, HDL コレステロール：デキストラン硫酸法, Apo A：ロケット免疫拡散法にてそれぞれ測定した。動物実 験ではウィスター系純系ラット $200 \mathrm{~g}$ 前後を使用した。 なお uremic toxin の middle molecules は従来の方法に より，限外濾液より抽出精製したものを使用 ${ }^{11)}$ ，また GSA, MG は市販の純品を使用した。

\section{結果}

\section{1）腎機能とSCBR}

腎機能の推移と SCBR の関係を検討したのが図 1 お よび図 2 である。慢性腎炎由来と考えられる図 1 の非糖 尿病群では, 腎機能の低下とともに SCBR の低下傾向が 見られ, GFR $>50 \mathrm{~m} l / \mathrm{min}$ 以上群 $(\mathrm{N}=12, \mathrm{SCBR}=$ $37.3 \pm 13.8 \mathrm{mg} / \mathrm{d} l)$ に比較し, $\mathrm{GFR}<10 \mathrm{~m} l / \mathrm{min}$ の腎不全 群 $(\mathrm{N}=16, \mathrm{SCBR}=27.4 \pm 12.1 \mathrm{mg} / \mathrm{d} l)$ および血液透析 群 $(\mathrm{N}=16, \mathrm{SCBR}=18.5 \pm 3.6 \mathrm{mg} / \mathrm{d} l)$ では $\mathrm{p}<0.1$ と有

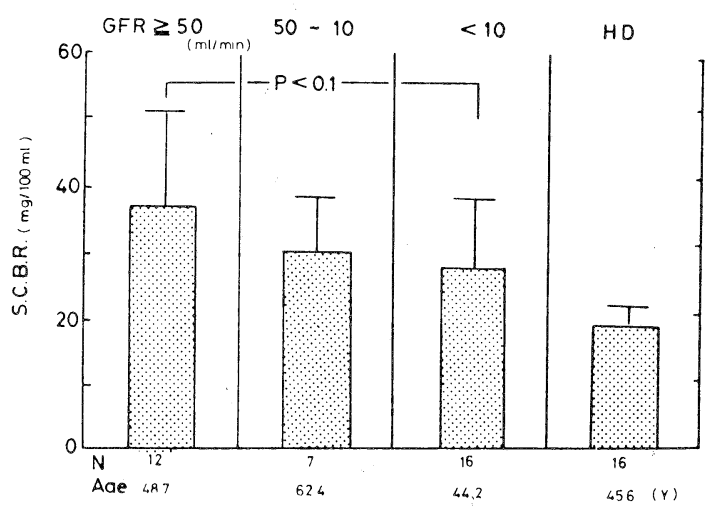

図 1 Correlation between SCBR and renal function without DM

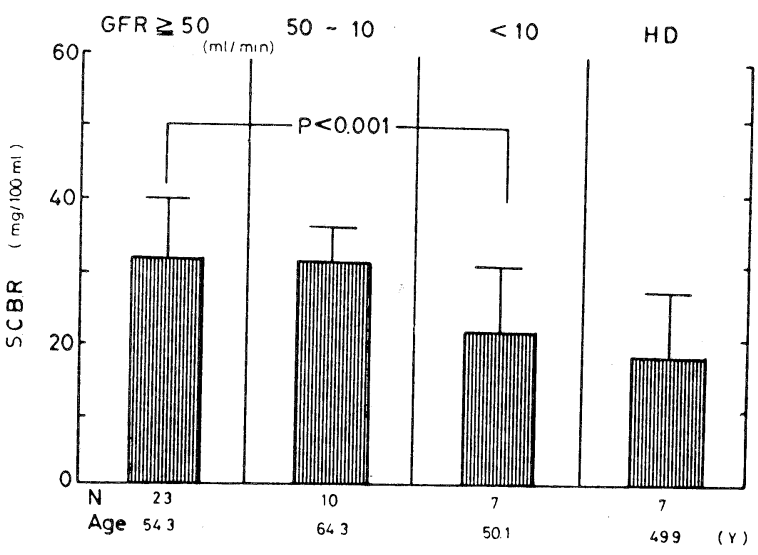

図 2 Correlation between SCBR and renal function with DM

意な低下を示した。図 2 の糖尿病に由来する腎機能障害 例においては図 1 の非糖尿病群に比較し, 全体に低值を 示す傾向がみられる. GFR $>50 \mathrm{~m} l / \mathrm{min}$ 群 $(\mathrm{N}=23$, $\mathrm{SCBR}=32.8 \pm 7.5 \mathrm{mg} / \mathrm{d} l)$ に比較し, 腎不全群 $(\mathrm{N}=7$, $\mathrm{SCBR}=21.3 \pm 8.7 \mathrm{mg} / \mathrm{d} l)$ および透析群 $(\mathrm{N}=7$, $\mathrm{SCBR}=20.3 \pm 11.5 \mathrm{mg} / \mathrm{d} l)$ と $\mathrm{p}<0.1$ で有意の低下を認 め, 糖尿病群, 非糖尿病群とも, 腎機能の低下とともに SCBRの低下傾向が見られた。

2 ) SCBR と血清脂質分画

図 $3 ， 4$ および 5 に示すように SCBR と血清脂質分 画, すなわちコレステロール, 中性脂肪, HDL コレステ ロールとのおのおの相関を検討したが，いずれも有意な 相関関係を見出すことはできなかった。

3 ) SCBRと LCAT 活性および Apo A 


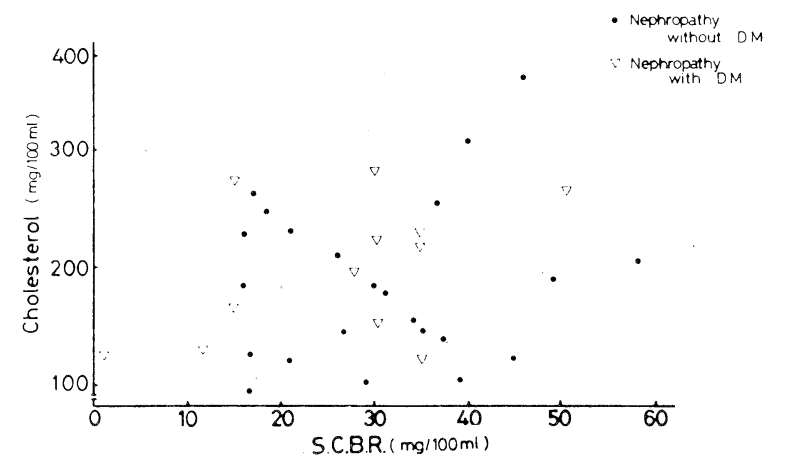

図 3 Correlation between SCBR and cholesterol

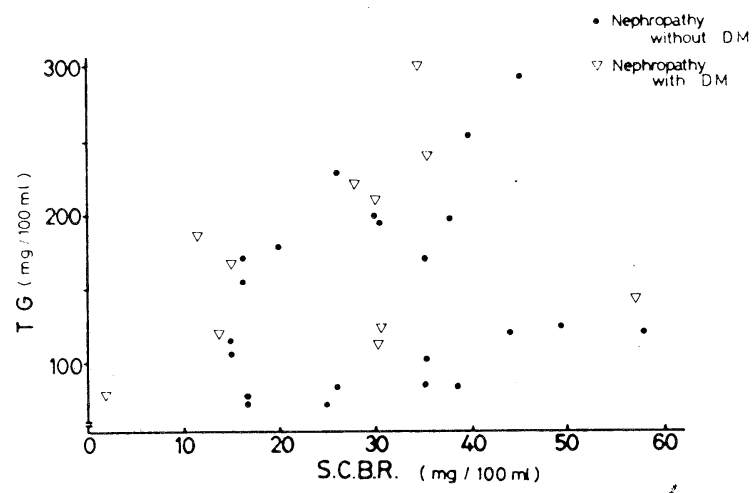

図 4 Correlation between SCBR and triglyceride

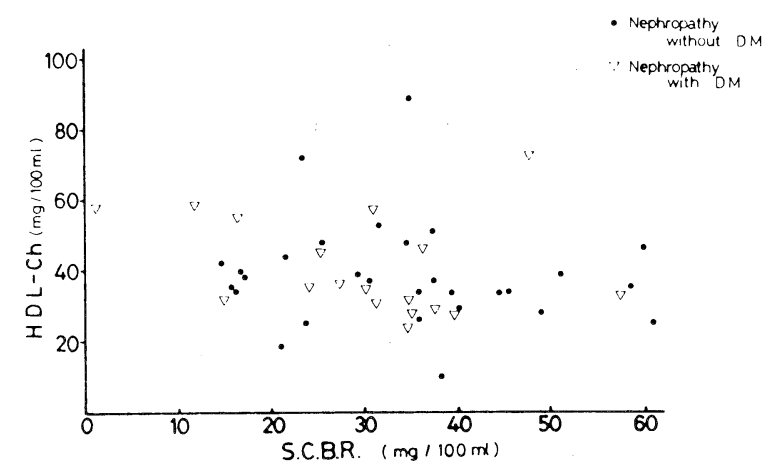

図 5 Correlation between SCBR and HDL-Cholesterol

図 6，7 に示すように SCBR と LCAT との相関を検 索したが, LCAT との間には $\gamma=0.54$ と軽度正の相関関 係を見，また SCBR とApo A との間にも $\gamma=0.53$ と軽 度正の相関関係がみられた。

\section{4) 透析患者における SCBR}

1 回約 5 時間の血液透析が SCBR にいかなる影響を 与えるかを検討するため便宜上次の 2 群に分けて観察し た。すなわち表 1 に示すごとく 17 名の血液透析患者を持

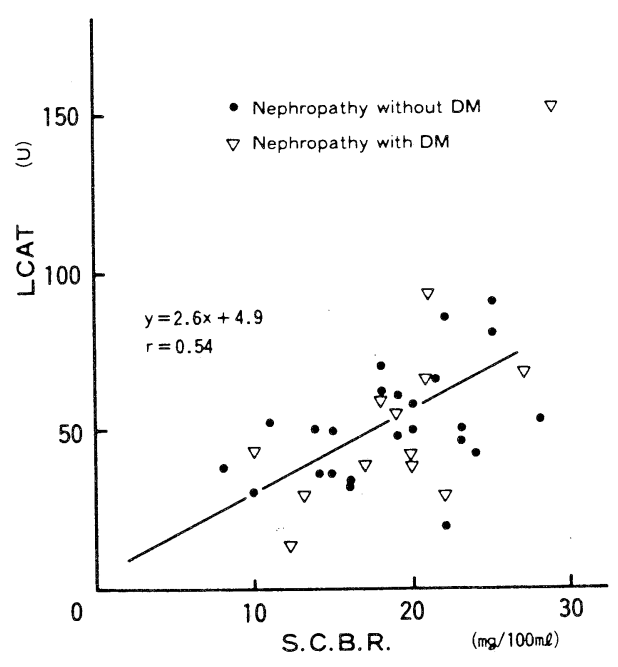

6 Correlation between SCBR and LCAT

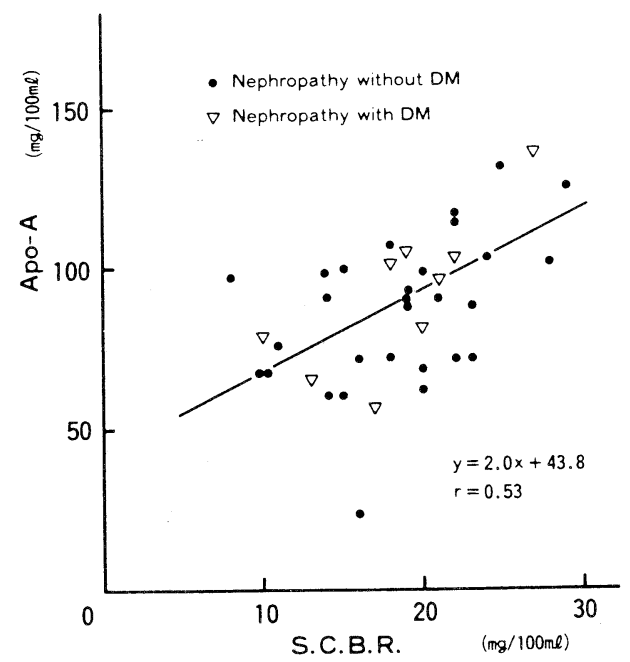

図 7 Correlation between SCBR and Apo-A

続的に SCBR が $20 \mathrm{mg} / \mathrm{d} l$ 以下の低値を示す群と, 20 $\mathrm{mg} / \mathrm{d} l$ 以上を示す群にわけた. $20 \mathrm{mg} / \mathrm{d} l$ 以下低值群では 糖尿病性腎不全で, 高頻度に低值例を認めたことは注目 される. 図 8 のごとく, 血液透析前の SCBR と直後の SCBR を比較検討すると, 全体に直後の SCBR が高值 を示す傾向にある. 少数例ではあるが, 不変の症例, お よび低下する例が認められた。この傾向は両群間におい て見られ，両群間に有意な相違を見出すことはできな かった.

5 ) in vivo における SCBR に対する uremic toxin の影響 


\begin{tabular}{c|c|c}
\hline & $\mathrm{SCBR}<20 \mathrm{mg} / \mathrm{d} l$ & $\mathrm{SCBR}>20 \mathrm{mg} / \mathrm{d} l$ \\
\hline $\begin{array}{c}\text { HD patients } \\
\text {-DM }\end{array}$ & $\begin{array}{c}\mathrm{N}=4 \\
\text { age }=59.0 \pm 11\end{array}$ & $\begin{array}{c}\mathrm{N}=1 \\
\text { age }=34\end{array}$ \\
\hline $\begin{array}{c}\text { HD patients } \\
\text {-non DM }\end{array}$ & $\begin{array}{c}\mathrm{N}=5 \\
\text { age }=42.0 \pm 9.5\end{array}$ & $\begin{array}{c}\mathrm{N}=9 \\
\text { age }=53.4 \pm 10\end{array}$ \\
\hline
\end{tabular}

表 1
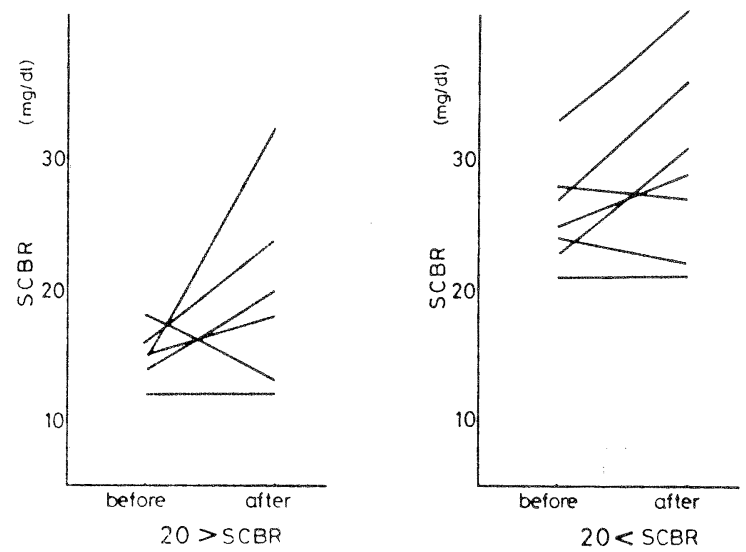

図 8 Effect of 5 hours HD on SCBR

次いで in vivo において uremic toxin の SCBR に対 する影響を検討した。ウィスター系 $200 \mathrm{~g}$ 前後のラット に uremic toxin である GSA, MG および middle molecules を尾静脈より静注後 30 分にて殺し, 採血前述 の方法で SCBR を測定した。いずれの群に扔いても軽度 の抑制傾向が認められたが，特に非糖尿病性腎不全より 得た middle molecules 添加群で $\mathrm{p}<0.1$ で有意の下降 が認められた。

\section{考案}

腎不全状態における代謝異常，特に脂質代謝異常につ いては，LPL 活性の低下，高 VLDL 血症，さらに dyslipoproteinemia 等について特異的なパターンの報告が すでにされてきた ${ }^{2,3)}$.これらの脂質代謝異常に引き続い て，腎不全患者において心血管合併症による死亡率が高 頻度に認められることが報告されている゙).さらに近年 Bagdade $^{5}$ 抢よび Rapoport ${ }^{6}$ 等は, 腎不全における HDL フラクションの減少，および LCAT 活性の低下を報告 し，これら一連の脂質代謝異常の結果，腎不全患者にお ける動脈硬化の進展が強く促進されることを報告し，腎 不全状態に扔けるコレステロール転送の意義が，さらに 重要視されるに至った.Hsia らは外因性コレステロール の血清成分による転送について，独持の方法で測定を試 み、いわゆる serum cholesterol bindig reserve (SCBR) と命名し, 心血管障害において著明に低下する事を認め,

\begin{tabular}{c|c|c}
\hline & $\mathrm{N}=$ & $\mathrm{SCBR}(\mathrm{mg} / 100 \mathrm{~m} l)$ \\
\hline Control & 5 & $17.1 \pm 3.9^{*}$ \\
\hline $\begin{array}{c}\mathrm{G} \mathrm{S} \mathrm{A} \\
(4 \mathrm{mg} / \mathrm{kg})\end{array}$ & 4 & $16.0 \pm 2.4$ \\
\hline $\begin{array}{c}\mathrm{MG} \\
(0.8 \mathrm{mg} / \mathrm{kg})\end{array}$ & 4 & $14.0 \pm 3.2$ \\
\hline $\begin{array}{c}\text { M. M.(non DM) } \\
4 \mathrm{mg} / \mathrm{kg})\end{array}$ & 4 & $12.6 \pm 3.2^{*}$ \\
\hline $\begin{array}{c}\text { M. M.(DM) } \\
4 \mathrm{mg} / \mathrm{kg}\end{array}$ & 4 & $13.7 \pm 2.4$ \\
\hline \multicolumn{2}{|c|}{} & $* \mathrm{P}<0.1$
\end{tabular}

表 2 Effects of uremic toxins on SCBR in vivo

動脈硬化性疾患と関連深い事実を報告し1)，さらに引き 続いて，ネフローゼ症候群においても SCBR の低下が認 められることを報告した ${ }^{7)}$ 。この際の血清成分へのコレ ステロール結合は HDL, LDL 分画のいずれにも結合し， LDLにおいてその結合度が高いことを報告している1 著者等の成績において，SCBR が腎機能の低下とともに 低值を示し，腎不全状態では，透析療法の有無にかかわ らず，有意の低值を認めることは興味深く腎不全状態に 扔けるコレステロールの転送異常を強く示唆する事実で ある。Hsia らも同様汇腎不全状態において，SCBR を 測定し, 糖尿病合併例に低值を示す症例のある事を報告 したが ${ }^{8,9)}$ ，この事実は，著者らの糖尿病性腎不全例にお いて異常低值例が，高頻度に認められる成績と一致して いる。しかしながら, 彼らは糖尿病を伴わない腎不全透 析例において，低下を認めず9，著者らと異なった成績を 示している。この点については，なお検討を必要とする が，著者らが行った，in vivoに打ける uremic toxin に よる SCBR の抑制は重要な示唆を与えるものであり,ま た長期透析患者に持続的低值を示す例が認められるこ と,さらに 1 回約 5 時間の血液透析前後の SCBR が大部 分の例で上昇を示す事は興味深い成績と考えられる。こ の SCBR の変動については，担体としてのリポ蛋白の uremic toxin 等による機能的, 質的変化を窺わせるが, この成績は他の物質および薬物においても, 腎不全血清 中の結合蛋白すなわちアルブミンの結合能の低下，阻害 についての報告 ${ }^{10)}$ と関連するものと考えられる。すなわ ちこれらの結合機能についての uremic toxin 等による 結合機能阻害，抑制が考えられ，腎不全状態における， 血中に多く存在する停滞物質の関与が想定される。

またこの SCBR は HDL コレステロールとは全く相 関関係を示さないが, 腎障害例で LCAT 活性, Apo A と各々軽度の正の相関を認めたことは, 測定法上の問題 をも含めて HDL の機能と多少とも関連を想定せしめる 
成績であった。

また腎不全状態に扔いて，その原因疾患としての糖尿 病のSCBR に対する関与について観察を行ったが，その 特徵として, GFR $<50 \mathrm{~m} l / \mathrm{min}$ 以下の群に扔いて, 非糖 尿病群に比較して, 全般に SCBR の低下傾向を示し, ま た表 1 に示したように持続的に低值を示す症例が高頻度 に認められ，血管障害の潜在を思わしめるが，予後との 関連を含めてな打検討課題と考える。

以上腎不全状態における脂質代謝変動について, SCBR の態度より検討したが，この低下の機構に関して は一部 uremic toxin 依存性であるが，1回透析後の SCBR の上昇は認められるものの, 長期慢性血液透析例 では, 一般にその回復が認められず, HDL コレステロー ルの態度と同様に，血液透析によってのみこれらの改善 は否定的であった。この事実は血液透析による脂質代謝 状態の改善効果が少ないことを示唆し，すなわち，蓄積 した uremic toxin の十分な除去が現状の血液透析療法 では不可能とも考えられるが，またこの SCBR の態度よ り見ても，な拈他の抑制因子の介在が想定される。

\section{結語}

慢性血液透析患者のコレステロール結合能を検索し た。糖尿病合併の有無にかかわらず腎機能の低下ととも に SCBR の低下を認めその原因として uremic toxin, 特に uremic middle molecules の関与が認められた。

1 回血液透析前後の SCBR の回復が認められたが, 長 期透析例では有意の回復は認められなかった。

\section{文献}

1) Hisia, S. L., Chao, Y.S., Hennekens, C. H., Reader, W. B. : Decreased serum cholesterol binding reserve in premature myocardial infarction. The Lancet, Nov. 22 ; 1000-1004, 1975.

2) Unoki Tetsuhide, : Serum high dencity lipoprotein in hemodialysis patients. Japanese Circulation Journal, vol. $42 ; 855-863,1978$.
3）高橋浩一, 石戸谷豊, 工藤達也, 足木淳男, 平山順 朗，鈴木唯司：慢性血液透析患者の脂質代謝に関す 了研究(第 2 報) 腎と透析，11( 5 )：583-588，1981。

4) Lindner, A., Charra, B., Sherrard, D., \& Scribner, B. : Accelrated atherosclerosis in prolonged maintenance hemodialysis. New Engl. J. Med. 290:697-700, 1974.

5) Bagdade, J. D., Porte, D. Jr., \& Bierman, E. L. : Hypertriglyceridemia : a metabolic conceqence of chronic renal failure. New Engl. J. Med. 279 ; 181-185, 1968.

6) Rapoport, J. Aviram, M., Chaimovitz, C., Brook, J. G. : Defective high dencity lipoprotein composition in patient on chronic hemodialysis. New Engl. J. Med. 299 ; 1326-1329, 1978.

7) Perez, G. O., Levine, S., Comez, E., \& Hisia, S. L. : Serum cholesterol bindig reserve in patient with the nephrotic syndrome. Nephron, $24 ; 146$ $-149,1979$.

8) Hsia, S. L., Fishman, L. M., Briese, F. W., Christakis, G., Burr, J \& Briker, L. A. : Decreased serum cholesterol binding reserve in Diabetes Mellitus. Diabetes Care, 1:89-93, 1978.

9) Perez, G. O., Hsia, S. L., Christakis, G., \& Burr, J. : Serum cholesterol binding reserve and high dencity lipoprotein cholesterol in patients on maintenance hemodialysis. Horm. Matab. Res. $12 ; 449-454,1980$.

10) Depner, T.A., Gulyassy, P. F., Stanfel, L. D., \& Jarrard, E. A. : Plasma protein binding in uremia ; Extraction and charactarization of an inhibitor. Kidney International, 18 : 86-94, 1980.

11）藤田嘉一，後藤武男：透析の病態生理 (糖代謝)。腎 不全のすべて.内科シリーズ, $18: 274-282$, 南江堂, 1975. 